\title{
Poverty, Social Exclusion and Homelessness in Conditions within the European Union
}

\section{T. Habanik (Tomas Habanik)}

Ss. Cyril and Methodius University in Trnava, Faculty of Social

Sciences, SK

\section{E-mail address:}

thomas.habanik@gmail.com

\section{Reprint address:}

Tomas Habanik

Ss. Cyril and Methodius University in Trnava

Faculty of Social Sciences

Bucianska 4/A

91701 Trnava

SK

Source: Clinical Social Work and Health Intervention

Pages: $33-41$
Volume: 9

Issue: 2

\section{Reviewers:}

Gabriela Lezcano

University of California, San Francisco, USA

Gunther Dorfmeister

Vienna General Hospital, Vienna, AT

\section{Key words:}

Poverty. Social exclusion. Homelessness. Material deprivation. New poor.

\section{Publisher:}

International Society of Applied Preventive Medicine i-gap

CSWHI 2018; 9(2): 33 - 41; DOI 10.22359/cswhi_9_2_05 @ 2018 Clinical Social Work and Health Intervention

\section{Abstract:}

The study aims to analyze the extent of poverty, homelessness and social exclusion in the European Union, in conjunction with identification of the population which combines selected risk factors for the emergence of potential homelessness. In drafting the study, data from the Eurostat website was used, where the focus was on analyzing the size of the population at risk of poverty after social 
transfers and suffering from material deprivation, along with estimates by the European Union Statistics on Income and Living Conditions (EU SILC) about the percentage of the EU population living in substandard living conditions. The study is an effort to point out that potential homelessness is a particularly timely issue, endangering the social sovereignty of a significant part of the EU population.

\section{Conflict of interest:}

The authors whose names are listed in the title of the article certify that they have NO affiliations with or involvement in any organization or entity with any financial interest (such as honoraria; educational grants; participation in speakers' bureaus; membership, employment, consultancies, or other equity interest), or non-financial interest (such as personal or professional relationships, affiliations, knowledge or beliefs) in the subject matter or materials discussed in this manuscript.

\section{Background}

Society is characterized by the presence of various social phenomena, with great contrasts able to be found inside it when, on the one hand, there exists great possibilities and opportunities and yet, on the other, various forms of uncertainty and social risk occur (Horakova, Horak, 2013).

Social risks are events whose impact limits the ability of either individuals or social groups to ensure social independence and sovereignty through their own capabilities. The presence of social risks so concerns individuals and social groups living in permanent uncertainty to make it impossible to reflect either the presence or positive anticipation of the future (Panzaru, 2013).

The consequences of uncontrolled social risks can be seen subsequently in this respect in the form of poverty and social exclusion, as well as the risk of the onset of other sociopathological phenomena associated with the processes of poverty and social exclusion (homelessness, substance abuse, family breakdown, etc.) (Vagnerova, Csemy, Marek, 2013). The issues of poverty, social exclusion and homelessness are particularly timely challenges the European Union (EU) is facing, where they can be met although on the one hand with the intention of the EU as a whole to eliminate deepening poverty, social exclusion and the homelessness that comes with both of them, while on the other hand with the differing attitudes the Member States have toward solving these phenomena.

\section{Theoretical Part}

In this context, it is important to stress that, in the case of poverty and social exclusion, no universal definition can be stated. Based on these aspects, only absolute and relative poverty cannot be defined (along with the subjective and objective concept), although other dimensions of poverty exist such as policy, demographics, transformation and employment (Ondrejkovic et al., 2009). Therefore, poverty and its multiple dimensions cannot be seen just as a process of simple deprivation, but also as concurrently incorporating a diverse set of partial deprivations that may include:

- Inadequate health framework (inability to treat a disease, risk of a shorter life); 
- Inadequate safety and security framework (insecure forms of housing, unhealthy living environment);

- Inadequate social security framework (dependence on the social system, inability to acquire quality education);

- Inadequate respect framework (limited possibilities and opportunities to participate in social possibilities and opportunities);

- Inadequate physical comfort framework (hunger, inadequate clothing) (Polonova, Matel, Romanova, 2011).

During the 1960s, Western European countries saw the advent of the "new poor", a term applied in conjunction with the effect of changing social and economic conditions and consequently to the relative vulnerability of different social categories among the poor as well as the consequent increase in inequalities within society. As such, the new poor is not reflected solely in relation to the absence of financial resources but also with a deep level of exclusion including other dimensions (Madanipour, Shucksmith, Talbot, 2015).

Among the accompanying phenomena in the concept of the new poor subsequently seen in advanced European countries is the definition of emerging new social risks, together with the following features:

- Onset of the phenomenon of the working poor characteristically mainly in the working poor whose level of income is so low that despite employment, that they are unable to meet their needs to the degree the remainder of the population can;

- Exposure to the risk of being unable to acquire skilled employment even though an individual has undergone a learning process and time, funds and effort have been invested into it; and
- Exposure to the risk of growing old in poverty reflected in demographic changes that are taking place in the structure of society, exposing risk in the capability and sustainability of the Social Security System (Ondrejkovic et al., 2009).

Some authors have argued about the process in the Social Sciences of moving from the concept of poverty to that of social exclusion, based on their interest in capturing the new features of poverty that are occurring in society. In this connection, persistent poverty and the spatial aspect thereof (accompanied in certain cases by marginalization) has been evident over time with signs of pathological behavior among the poor; dependence on the government's social system; disintegration of traditional social institutions (such as family); in the defiance expressed by those affected by poverty against the value stream in society. In the context of social exclusion there are individuals and entire groups of citizens deprived of participation in regular activities which are associated with citizenship itself (Mares, Sirovatka, 2008). It is important therein to emphasize the multidimensional nature of social exclusion whose concept goes beyond the explanatory framework of poverty in two determinants:

- Social exclusion does not have to strictly be just the type of exclusion caused by the absence of sufficient material and financial resources;

- Awareness of the processes and mechanisms putting someone at risk (or increasing risk) of social exclusion, whether at the level of individuals or social groups (Cambalíkova, Sedova, 2007).

Social exclusion likewise includes the following specific characteristics generally accepted in the Social Sciences: 
- Social exclusion has the nature of a dynamic concept involving not only the current scope that covers the absence of resources, but also the nature of limited outlook and prospects for the future;

- Social exclusion is a relative concept that plays out in the context of a specific type of society at a particular time horizon, while taking into account the activities of other people complemented by the acquisition of various types of addictions (example - geographic factors);

- Social exclusion can mean an implied wider comprehension of a deprived standard of living;

- There is a particularly sharp focus on the actor or actors;

- Emphasis is placed on the level of the relationship and social links between individuals, groups and society; something reflected in the focus on social participation and isolation, the absence of power and the like (Gerbery, Dzambazovic, 2011).

However, a frequent phenomena found in practice is the connectivity between the concepts of poverty and social exclusion which significantly influence the overall nature of social status and the level of health in an individual trapped in the circle of poverty and social exclusion (Poverty, social exclusion and health systems in the WHO European Region, 2010).

In developed countries, it is just poverty and social exclusion that are the main factors in homelessness (Shinn, 2010) whose timeliness and severity is accompanied not just by a constant increase in the number of people living permanently homeless in the EU, but also in the growing number of people constantly at risk of becoming homeless. So how homelessness appears and the form it takes can be different defining both obvious hidden and potential homelessness (Veres, 2008).
Consequently, social exclusion can be seen in connection with homelessness as an extreme form while it is a multi-faceted problem consisting of the operation and interconnection between subjective and objective factors (Vagnerova, Csemy, Marek, 2014). Homelessness itself needs to be understood as the social decline of people who have not only lost their homes but also have become subject to social exclusion across multiple dimensions. Homeless people are unable to ensure or maintain their own permanent and adequate housing due to the absence of adequate financial resources (Hradecky, 2008).

In this context, however, it is necessary to draw attention to the exposure of the potentially homeless (individuals and entire families) to the real risk of losing their homes or of living in inadequate facilities inappropriate for health (Dvorackova et al., 2016). Perceiving and addressing homelessness in the EU can be met in Member States with differing attitudes. A definition and typology of homelessness called ETHOS (European Typology of Homelessness and Housing Exclusion) presented by the European Federation of National Organizations Working with the Homeless (FEANTSA), an organization raising awareness of obvious homelessness and also primarily of the potential of homelessness, has been applied at the EU level (Bartosovic, 2016). Potential homelessness affects individuals (and entire families) living in an unsatisfactory or unsuitable environment, and also anyone exposed to the constant risk of eviction from their homes. Here potential homeless can also include in this context people whose income is low despite employment (the "working poor") or who have found themselves at risk of poverty and material deprivation becoming exposed to significantly greater risk of social exclusion than the remaining population (Bratt, Stone, Harman, 2006). 


\section{Methods}

In terms of researching the issue, we decided to proceed with an analysis of selected factors that endanger the social independence of individuals and social groups living in the EU. Attention is drawn in this context to developments in the extent to which the EU population is actually at risk of material deprivation and poverty after social transfers in conjunction with an analysis of estimates by EU SILC about the percentage of the population living in inappropriate, inadequate and uncertain conditions. It is by analyzing the factors that awareness can be raised not just about the issue of a significant part of the EU populations continuing inadequate securing of subsistence, but also in the exposure to the potential risk of homelessness which at present is exceptionally timely from the perspective of a society still not giving it due attention. Likewise, our intention was to examine whether the objectives in the Europe 2020 Strategy are being met with regard to minimizing poverty, social exclusion and homelessness. In implementing this study statistical data from Eurostat was used for the period under observation covering the 2010-2015 horizon.

\section{Results and discussion}

At the EU level, several documents have been drafted and action taken to eliminate deepening poverty, social exclusion and homelessness. The current communication is Europe 2020 - A strategy for smart, sustainable and inclusive growth whose time horizon covers ten years (2010-2020). Selected, ambitious goals can be mentioned in connection with research into the issue touching upon having achieved 75\% employment among the EU population aged 20-64 years and $40 \%$ of the university educated population aged 30-34 years, while mainly lowering the number of people at risk of poverty and social exclusion by 20 million (realized through initiatives launched by the European Platform Against Poverty and Social Exclusion) alongside the seeking of solutions to minimize long-term homelessness and establishing preventive action against homelessness. Likewise, the objective consists also of support for the process of intensive cooperation between the Member States and European Institutions, in conjunction with support and cooperation among other players at not just the European level but also the national and regional levels, too (Habanik, 2017).

Table 1: EU population at risk of poverty after social transfers and material deprivation (source http://ec.europa.eu/eurostat).

\begin{tabular}{|l|c|c|c|c|c|c|}
\hline geoltime & $\mathbf{2 0 1 0}$ & $\mathbf{2 0 1 1}$ & $\mathbf{2 0 1 2}$ & $\mathbf{2 0 1 3}$ & $\mathbf{2 0 1 4}$ & $\mathbf{2 0 1 5}$ \\
\hline $\begin{array}{l}\text { Population } \\
\text { on 1 Janu- } \\
\text { ary }\end{array}$ & 503170618 & $\begin{array}{r}502964837 \\
(-0,04 \%)\end{array}$ & $\begin{array}{c}504060345 \\
(+0,18 \%)\end{array}$ & $\begin{array}{r}505166839 \\
(+0,40 \%)\end{array}$ & $\begin{array}{r}506973868 \\
(+0,76 \%)\end{array}$ & $\begin{array}{c}508504320 \\
(+\mathbf{1 , 0 6 \% )}\end{array}$ \\
\hline $\begin{array}{l}\text { People at } \\
\text { risk of po- } \\
\text { verty after } \\
\begin{array}{l}\text { social } \\
\text { transfers }\end{array}\end{array}$ & 81860000 & $\begin{array}{r}83747000 \\
(+2,31 \%)\end{array}$ & $\begin{array}{r}83953000 \\
(+2,56 \%)\end{array}$ & $\begin{array}{r}83331000 \\
(+1,80 \%)\end{array}$ & $\begin{array}{r}85926000 \\
(+4,97 \%)\end{array}$ & $\begin{array}{c}86752000 \\
(+5,98 \%)\end{array}$ \\
\hline $\begin{array}{l}\text { Severely } \\
\text { materially } \\
\text { deprived } \\
\text { people }\end{array}$ & 41631000 & $\begin{array}{r}43953000 \\
(+5,58 \%)\end{array}$ & $\begin{array}{r}49449000 \\
(+18,78 \%)\end{array}$ & $\begin{array}{r}48034000 \\
(+15,38 \%)\end{array}$ & $\begin{array}{r}44441000 \\
(+6,75 \%)\end{array}$ & $\begin{array}{c}\mathbf{( - 3 , 0 5 \% )} \\
(40361000\end{array}$ \\
\hline
\end{tabular}


A positive step can be considered a draft European strategy to address homelessness, including 36 specific points that were presented at the plenary session of the Commission for Economic and Social Policy (ECOS) from workshops run by the Committee of the Regions. The document highlights the existence of different approaches toward addressing the issue in terms of individual countries. Selected points in the strategy include acceptance of the right to decent housing as a basic human need; provision of emergency/temporary housing, with a preference toward prevention over resolution of the consequences of homelessness; and in particular to create affordable and social housing for people with low incomes which would constitute the basis for preventing homelessness (Draft opinion - A European homelessness strategy, 2014).

In the research period 2010-2015 the number of people at risk of poverty after social transfers rose in parallel with the EU's population which over the period grew by $4,892,000$ people, amounting to a $5.98 \%$ increase over the original baseline status. In this respect, the same can be said of the

Table 2: Percentage of the EU population in unsatisfactory living conditions (source http:// ec.europa.eu/eurostat).

\begin{tabular}{|c|c|c|c|c|c|c|}
\hline geoltime & 2010 & 2011 & 2012 & 2013 & 2014 & 2015 \\
\hline $\begin{array}{l}\text { Population } \\
\text { on } 1 \text { Janu- } \\
\text { ary }\end{array}$ & 503170618 & 502964837 & 504060345 & 505166839 & 506973868 & 508504320 \\
\hline $\begin{array}{l}\text { Total popu- } \\
\text { lation ha- } \\
\text { ving neither } \\
\text { a bath, nor } \\
\text { a shower, } \\
\text { nor indoor } \\
\text { flushing to- } \\
\text { ilet in their } \\
\text { household } \\
\text { - EU-SILC } \\
\text { survey }\end{array}$ & $2,6 \%$ & $\begin{array}{c}2,4 \% \\
(-0,20 \%)\end{array}$ & $\begin{array}{c}2,3 \% \\
(-0,30 \%)\end{array}$ & $\begin{array}{c}2,2 \% \\
(-0.40 \%)\end{array}$ & $\begin{array}{c}2,1 \% \\
(-0,50 \%)\end{array}$ & $\begin{array}{c}2,0 \% \\
\mathbf{( - 0 . 6 \% )}\end{array}$ \\
\hline $\begin{array}{l}\text { Total popu- } \\
\text { lation living } \\
\text { in a dwe- } \\
\text { lling with } \\
\text { a leaking } \\
\text { roof, damp } \\
\text { walls, floors } \\
\text { or founda- } \\
\text { tion, or rot } \\
\text { in window } \\
\text { frames of } \\
\text { floor - EU- } \\
\text { SILC survey }\end{array}$ & $16,1 \%$ & $\begin{array}{c}15,6 \% \\
(-0,50 \%)\end{array}$ & $\begin{array}{l}15,1 \% \\
(-1 \%)\end{array}$ & $\begin{array}{c}15,6 \% \\
(-0.5 \%)\end{array}$ & $\begin{array}{c}15,7 \% \\
(-0,40 \%)\end{array}$ & $\begin{array}{c}15,2 \% \\
\mathbf{( - 0 , 9 \% )}\end{array}$ \\
\hline
\end{tabular}


average year-on-year increase in poverty by $3.52 \%$. 2011 and 2014 would be classified by us as the most significant years in terms of the growth in poverty. (Ironically, 2010 had been declared the European Year for Combating Poverty and Social Exclusion).

In 2010, 41,631,000 people were stricken by material deprivation; while the population at the end of the observation period was 40,361,000, a decrease of $1,270,000$ people and a decline of $3.05 \%$ from the baseline figure. On the other hand, attention should be paid to developments in material deprivation mainly in 2011 and 2012 when the number of people suffering from material deprivation rose to $5.58 \%$ and $18.78 \%$ of the EU population, respectively. Nevertheless, a decline in the number of people suffering from material deprivation was able to be achieved and average growth in values were $8.69 \%$ annually.

In terms of the EU-SILC survey, the same attention was given to estimates on the proportion living in housing that is unsatisfactory or uncertain, or living in unreasonable health conditions to the total EU population. With regard to housing conditions, specific indicators are highlighted such as the lack of bathrooms and flush toilets, moisture in walls and leaking roofs, poorly sealed windows, the presence of mold, lack of light, noisy environment, etc. In analyzing the data, it can be stated during the period under observation that there had been a drop in the percentage of the population showing the typical signs of potential homelessness with part of the population at risk not only in terms of health, but also in view of their social sovereignty and independence.

On the other hand, uncertain, inadequate and unsatisfactory living conditions for health are continually faced by a significant part of the EU population. It is just in this context to be able to talk about an interconnection between poverty, homelessness and social exclusion. People who do not have enough resources to secure quality housing are forced to dwell in unsatisfactory areas or to be socially excluded across multiple dimensions with constant exposure to the risk of homelessness caused by the impact of poverty and multidimensional social exclusion influencing the consequent life of those individuals and entire groups of people so affected.

\section{Conclusion}

Poverty and social exclusion can be classified as persistent social phenomena within society. The consequences of these phenomena are subsequently reflected in the presence and rise of sociopathological phenomena which may include even homelessness. In this context, the interdependence of poverty and social exclusion undermining social sovereignty in a significant part of the EU's population, needs to be stressed alongside the process of essentially seeking long-term and comprehensive opportunities to address the issue.

\section{References}

1. BARTOSOVIC I (2016) Some aspects of the health status of homeless people. Clinical Social Work and Health Intervention, 7(1), pp. 39-47.

2. BRATT R G, STONE M E, HARTMAN CH (2006) Right to Housing: Foundation for a New Social Agenda. Philadeplhia, Temple University Press, 448 p. ISBN 1-59213432-7.

3. CAMBALIKOVA M, SEDOVA T (2007) Exclusion and social situation in Slovakia. Sladkovicovo, Danubius University, 2007, 328 p. ISBN 978-80-89267-07-1.

4. COMMITTEE OF THE REGIONS (2014) Draft opinion - A European homelessness 
strategy. [online]. [cited 16.12.2017]. Available at: http://www.borbolycsaba. ro/en/wp-content/uploads/2013/04/EN ECOS_V-058_draft-opinion_A-European-homelessness-strategy.pdf.

5. DVORACKOVA D, BELESOVA R, KAJANOVA A, BERGOUGNI B (2016) Health and social aspects of homelessness. Contact, 18 (3), pp. 196-201.

6. EUROSTAT (2017) People at risk of income poverty after social transfers. [online]. [cited 08.12.2017] Available at: http:// ec.europa.eu/eurostat/tgm/refreshTableAction.do?tab=table \& amp;plugin=1\&amp;pcode $=$ sdg_01_20\&amp;language $=$ en .

7. EUROSTAT (2017) Population change Demographic balance and crude rates at national level. [online]. [cited 16.12.2017] Available at: http://appsso.eurostat.ec.europa.eu/nui/show.do?dataset=demo_ gind\&amp;lang=en.

8. EUROSTAT (2017) Severely materially deprived people. [online]. [cited 10.12.2017] Available at: http:// ec.europa.eu/eurostat/tg m/table. do?tab=table\&amp;init=1\&amp; language=en\&amp;pc ode=t2020_53\&amp; plugin $=1$.

9. EUROSTAT (2017) Share of total population living in a dwelling with a leaking roof, damp walls, floors of foundation, or rot in window frames of follr - EU-SILC survey. [online]. [cited 11.12.2017] Available at: http://ec.europa.eu/eurostat/tgm/ table.do?tab=table \&amp;init=1\&amp ; l anguage $=$ en $\&$ a m p ; p code $=$ te s si292\&amp;plugin $=1$.

10. EUROSTAT (2017). Total population havin neither a bath nor a shower, noc indoor flushing toilet in their hosehold - EUSILC survey. [online]. [cited 11.12.2017] Available at: http://appsso.eurostat.ec.europa.eu/nui/show.do?dataset=ilc_mdho05\&amp;lang=en.

11. GERBERY D, DZAMBAZOVIC R (2011) Innovative orientations in social policy:
Perspective of social inclusion. Bratislava, Comenius University, 2011, 128 p. ISBN 978-80-223-2998-9.

12. HABANIK T (2017) Dimensions of poverty and homelessness in the European union. In Bocakova O, Kubickova D, Habanik T (ed). Comprehensive view of the issue social services and the social-political significance of their support. Gdansk: Research Institute for European Policy, 2017, pp. 71-103, ISBN 978-83-944614-5-4.

13. HORAKOVA M, HORAK P (2013) Employability of Groups at Risk of Unemployment in the Current Labor Market. Slovak Sociological Review, 45(2), p. 128-149.

14. HRADECKY I (2008) Building Capacity of Homeless Services in the Czech Republic. European Journal of Homelessness, 2(1), pp. 177-190.

15. MADANIPOUR A, SHUCKSMITH, M, TALBOT H (2015) Concepts of poverty and social exclusion in Europe. Local Economy: The Journal of the Local Economy Policy Unit, United Kingdom, 30(7), pp. 721-741.

16. MARES P, SIROVATKA T (2008) Social Exclusion and Social Inclusion - Concepts, Discourse, Agenda. Czech Sociological Review, 44(2), pp. 271-294.

17. ONDREJKOVIC P et al. (2009) Social pathology. Bratislava, SCIENCE, 2009, 553 p. ISBN 978-80-224-1074-8.

18. PANZARU C (2013) Risk factors for unemployment, Social security taxes. Social work Review, 12(4), pp. 1-9.

19. POLONOVA J, MATEL A, ROMANOVA E (2011) Poverty and homelessness. In Matel A, Schavel M, a kol. Applied social pathology in social work. Bratislava, St. Elizabeth University of Health and Social Work, 2011, pp. 376 -429, ISBN 978-80-8132-009-5.

20. SHINN M (2010). Homelessness, Poverty and Social Exclusion in the United States and Europe. European Journal of Homelessness, 4(1), pp. 19-44.

21. VAGNEROVA M, CSEMY L, MAREK J (2013) Homelessness as the alternative 
existence of young people. Praha, Karolinum Press, 2013, 337 p. ISBN 978-80-2462209.

22. VAGNEROVA M, CSEMY M, MAREK J (2014) Homelessness Among Young People in Prague. Praha, Karolinum Press, 2014, 226 p. ISBN 978-80-246-2587-4.
23. VERES M (2008) Most typical causes of homelessness in seniors. Contact, X(2) pp. 326-333.

24. WORLD HEALTH ORGANIZATION (2010) Poverty, social exclusion and health systems in the WHO European Region. Copenhagen, WHO Regional Office for $\mathrm{Eu}-$ rope, 2010, 33 p. ISBN 9789289002110. 